\title{
AYLIK KONUT SATIŞLARININ MODELLENMESI VE ANTALYA ÖRNEĞİ
}

Makale Gönderim Tarihi: 18.09.2018

Yayına Kabul Tarihi: 12.05.2020

\section{Hilal YILMAZ}

Yüksek Lisans Öğrencisi

Akdeniz Üniversitesi

İktisadi ve İdari Bilimler

Fakültesi

Türkiye

hilalylmz_32@hotmail.com

ORCID ID: 0000-0001-58446978

\section{Ömür TOSUN}

Doç. Dr., Akdeniz Üniversitesi Uygulamalı Bilimler Fakültesi Türkiye

omurtosun@akdeniz.edu.tr

ORCID ID: 0000-0003-15717373

ÖZ
Talep tahmini işletmelerin ve bireylerin geleceğe yönelik uygulayacağı stratejileri ve önlemleri almaları için yapmaları gereken önemli faaliyetlerden birisidir. $\mathrm{Bu}$ faaliyet kısaca bir hizmet veya ürün için gelecekte oluşacak olan talebin, en doğru ve hatasız bir şekilde hesaplanması sürecidir ve rekabetin yoğun olduğu günümüzde, üretim ve hizmet sektörlerinde işletmelerin ürünlerinin veya vermiş oldukları hizmetlerin sürdürülebilirliği açısından yaşamsal öneme sahiptir. İstatistiksel tahmin metotlarının yanında yapay zeka teknikleri de günümüzde talep tahmini için etkin bir şekilde kullanılmaktadır. Bu çalışmada Antalya ilinde konut taleplerinin tahmini Eviews programı ile çok değişkenli doğrusal regresyon analizi ile elde edilmiştir. Aynı veri seti için Matlab programı yardımıyla ileri beslemeli geri yayılımlı yapay sinir ağları kullanılarak da tahminler yapılmış ve sonuçların geçerliliği ile ağın performans1 regresyon modeli ile elde edilen sonuçlarla karşılaştırılmıştır. Yapılan karşıllaştırma doğrultusunda regresyon analizinin ortalama $\% 9$ hata değerine sahipken yapay sinir ağı tahmin modelinin $\% 1$ hata değerine sahip olduğu tespit edilmiştir. Dolayısıyla bölgesel konut satış modeli için yapay sinir ağlarının daha başarılı olduğu tespit edilmiştir.

Anahtar Kelimeler: Konut Satışl Tahmini, Yapay Sinir Ağları, Çoklu Regresyon Analizi

JEL Kodu: C30, C45, R21

Alant: Işletme

Türü: Araştırma

DOI: 10.36543/kauiibfd.2020.007

Atıfta bulunmak için: Yılmaz, H., Tosun, Ö. (2020). Aylık konut satışlarının modellenmesi ve Antalya örneği. KAÜIIIBFD, 11(21), 141-158. 


\title{
MODELLING MONTHLY HOUSING SALES AND EXAMPLE OF ANTALYA
}

\author{
Article Submission Date: 18.09.2018 Accepted Date: 12.05.2020_ Kafkas Üniversity \\ Economics and Administrative \\ Sciences Faculty \\ KAUJEASF \\ Vol. 11, Issue 21, 2020 \\ ISSN: $1309-4289$ \\ E - ISSN: 2149-9136
}

Hilal YILMAZ

Graduate Student, Akdeniz University, Faculty of

Economics and

Administrative Sciences

Turkey

hilalylmz32@hotmail.com

ORCID ID: 0000-0001-

5844-6978

\section{Ömür TOSUN}

Assoc. Prof.

Akdeniz University

Faculty of Applied Sciences

Turkey

omurtosun@akdeniz.edu.tr

ORCID ID: 0000-0003-

1571-7373

\begin{abstract}
Forecasting is one of the }}$ most important activities that must be undertaken in order to take the strategies and measures that the businesses and the individuals will implement in the future. This process is determining the future demand for a service or product in the most accurate and errorfree manner, and in today's competitive environment it has vital importance for the sustainability of the products or the services of the enterprises they provide. In addition to statistical estimation methods, artificial intelligence techniques are effectively used for demand forecasting. In this study, housing demand in Antalya province were estimated using multi-variable linear regression analysis with the EViews program. Estimations were also made using feed forward backpropagation artificial neural networks for the same data set using the Matlab program, and the validity of the results and network performance were compared against the results obtained with the regression model. According to the performance comparison, regression analysis has $9 \%$ mean error whereas artificial neural networks shows $1 \%$. Therefore, for the regional housing sale prediction model artificial neural networks show better results.
\end{abstract}

Keywords: Housing Sales Forecasting, Artificial Neural Networks, Multiple Regression Analysis

Jel codes: $C 30, C 45, R 21$

Scope: Business

Type: Research

Cite this Paper: Y1lmaz, H., Tosun, Ö. (2020). Modelling monthly housing sales and example of Antalya. KAUJEASF, 11(21), 141-158. 


\section{GİRIS}

İktisadi anlamda talep, tüketicilerin bir mal veya hizmeti belirli bir fiyat seviyesinde almaya hazır oldukları miktara denir. Tahmin yapmak veya tahminde bulunmak kişinin gün içinde yaptığı eylemlerin bir parçasıdır ve verdiği birçok karar da bu tahminlerden yola çıkarak yaptıkları bir faaliyettir (Top \& Yılmaz, 2009, s. 234). Talep tahmini de işletmenin üretmiş olduğu mal ve hizmetlere olan talebin geleceğe yönelik yapılması işlemine denmektedir (Tekin, 1996, s. 210). İşletmeler için talep tahmini önemli iş fonksiyonlarından biridir. Çünkü tüm iş kararları geleceğe yönelik bir tahmine dayanır. Hangi pazarı takip edeceği, hangi ürünü üretmesi gerektiği, kaç kişi işe alacağ gibi birçok konuda tahmin yapılması gerekmektedir. Kötü tahmin, yanlıș iş kararları sonucuna yol açar. Şirket gelecekteki talepleri karşılamada hazırlıksızdır. Kayıp satışlar açısından çok masraflı ve hatta şirketin işinde kötü sonuçlar doğurabilir (Reid \& Sanders, 2011, s. 265).

Talep tahmini fonksiyonunun temel görevi ise işlerin planlanmasında doğru bir tahmin sisteminin elde edilmesi için en önemli yöntemleri bulmak ve göstermektir (Nahmias, 2009, s. 52). Planlama işletmenin önemli ve ayrılmaz bir bölümüdür. Ancak, geleceğe yönelik belirsizlikler planlamanın gerçekleşmesini güçleştirmektedir. Dolayısıyla, ortaya çıkan belirsizliği azaltmak için bir takım yöntemler kullanılır. Tahminlerin doğruluğu işletmeler açısından önemlidir ve bunların işletme için sağlıklı olabilmesi bilimsel bir çalışma gerektirir (Üreten, 2006, s. 112).

Duyarlık, maliyet ve zaman tasarrufu talep tahmininde kullanılacak yöntem için önemlidir. İlk olarak hangi tahmin yönteminin kullanılacağ 1 seçiminde tahmin sürecinin iyi belirlenmesi ve daha sonra da çeşitli faktörlerin gözden geçirilmesi gerekmektedir. Bunlar yöneticinin kullanılacak yöntem hakkındaki bilgi düzeyi, tahmin için gerekli hazırlık süresi, karar verme dönemi, güvenirlik ve karar vericinin nitelikleri olarak açıklanabilir (Kobu, 2014, s. 131).

Çalışmanın takip eden bölümünde tahmin modelinde kullanılacak yapay sinir ağlarının genel özellikleri anlatılacaktır. Üçüncü bölümde yapay sinir ağları ve regresyon analizini birlikte kullanan çalışmalara ilişkin bir literatür analizi verilecektir. Dördüncü bölümde ise modelde kullanılacak değişkenler anlatılacak ve elde edilen model verilecektir. Uygulama kısmında Antalya ili için aylık konut satış tahmini amaçlanmıştır. Bunun için 01.2013-12.2017 yılları arasındaki aylık veriler kullanılmıştır. Bu verilerden 2013-2016 yılları arasındaki aylık veriler eğitim verisi, 2017 y1lı veriler de test verisi olarak ayrılmıştır. İlk olarak regresyon analizi yapılmıştır. Regresyon analizi için varsayımlar bulunmaktadır. Analiz yapabilmek için kullanılacak varsayımlara 
uyulması gerekmektedir. Birçok deneme yanılma yöntemi ile varsayımlara uygun model seçilmiştir. Bu model için kullanılacak değişkenler daire sayısı, konut değerleri, konut kredileri, konut kredi faiz oranı ve inşaat güven endeksi olarak belirlenmiştir. Bu değişkenler ile regresyon analizi yapılarak katsayılar yorumlanmıştır. Regresyon analizi ile elde edilen sonuçlarının karşılaştırılması için, talep tahmini uygulamalarında sıklıkla tercih edilen ve herhangi bir ön varsayım içermeyen yapay sinir ağları kullanılmıştır. Birebir karşılaştırma olabilmesi için regresyon modelindeki aynı değişkenler kullanılmıştır. Son olarak da yapılan analizlerin sonuçları gerçeğe uygunluklarıyla karşılaştırılarak yorumlanmıştır.

\section{YAPAY SİNIR AĞLARI}

Yapay sinir ağlarının tarihçesi insanların keşfetme ve öğrenmeye olan merakından doğmaktadır. Bu nedenle nörobiyoloji konusuna ilgi duyması ile elde edilen bilgileri bilgisayar bilimine uygulamaları ile başlamıştır. Yapay sinir ağları, biyolojik sinir ağlarının yapısını ve işlevselliğini taklit etmektedir.

Yapay sinir ağları (YSA), insan beyninin özelliklerinden olan öğrenme ile bilgi türetebilme, yeni bilgiler oluşturabilme ve keşfedebilme gibi yetenekleri herhangi bir yardım almadan otomatik olarak gerçekleştirmek amacı ile geliştirilen bilgisayar sistemleridir. Bu yetenekleri geleneksel programlama yöntemleri ile gerçekleştirmek oldukça zordur veya mümkün değildir. $O$ nedenle yapay sinir ağlarının, programlaması çok zor veya mümkün olmayan olaylar için geliştirilmiş adaptif bilgi işleme ile ilgilenen bir bilgisayar bilim dalı olduğu söylenebilir (Öztemel, 2016, s. 29).

YSA'lar eş zamanlı işlem yapan basit sinir hücrelerinden meydana gelmiştir. $\mathrm{Bu}$ elemanlar biyolojik sinir sistemlerine benzetilerek ortaya konulmuştur. Doğa işleyişine benzetilerek elemanlar arasındaki ilişki bir şebeke yoluyla sağlanmıştır. Bu şekilde bir şebekede bulunan elemanlar arasındaki ilişki ağırlıklarla temsil edilmektedir. Bu ağırlıklar girdi ve çıktı verilerine göre eğitilerek elde edilen çıktıların katkı oranları her biri için tek tek hesaplanır.

Yapay sinir hücreleri, biyolojik sinir hücreleri ile aynı yapıdadır. Yapay sinir ağları yapay nöronların aralarında bağ kurması ile oluşur. Yapay sinir ağlarında biyolojik sinir ağlarındaki nöronlar gibi giriş sinyallerini alırlar ve bu aldıkları sinyalleri işleyerek, çıktı birimine iletirler. Bir yapay sinir hücresi beş ana bölümden oluşmaktadır (Çayıroğlu, 2015, s. 7);

- Girdi,

- Ağırlıklar,

- Toplam fonksiyonu (Birleştirme fonksiyonu),

- Aktivasyon fonksiyonu, 
- Çıktılar,

Girdiler: Bir yapay sinir hücresine diş dünyadan ya da diğer hücrelerden gelen bilgilerdir.

Ağırlıklar: Yapay sinir hücresine gelen girdi bilgilerinin, birleştirme fonksiyonuna ulaşmadan önce, geldikleri girdi bilgi bağlantılarının ağırlıklarıyla çarpılır ve birleştirme fonksiyonuna iletilir. Böylelikle, girdilerin çıtı üzerindeki etkisini ayarlayabilmektedir. Ağırlıklar pozitif, negatif veya sıfır olabilmektedir. Ağırlı̆̆ı sıfır olması çıktı üzerinde herhangi bir ağırlığının olmadığını göstermektedir.

Toplama Fonksiyonu (Birleştirme Fonksiyonu): Toplama fonksiyonu hücrenin net girdisini, girdi değerleri ile ağırlıkların çarpılması ve bulunan değerlerin toplanması ile hesaplamaktadır.

Aktivasyon Fonksiyonu: Aktivasyon fonksiyonu, hücreye gelen net girdiyi işleyerek hücrenin bu girdiye karşılık üreteceği çıktıyı belirlemektedir. Aktivasyon fonksiyonu için genellikle doğrusal olmayan bir fonksiyon seçilmektedir.

Hücrenin Çıktısı: Aktivasyon fonksiyonu ile elde edilen değer hücrenin çıktısıdır. Bu elde edilen çıktı değeri yapay sinir ağının çıktısı olarak dışarıya verilir. $\mathrm{Bu}$ değer daha sonra istenildiği takdirde tekrar kullanılabilir. Yapay sinir ağlarında her hücrede birden fazla girdi ve bir tek çıktı vardır. Elde edilen bu çıktılar istenildiği sayıda hücre ile birleştirilebilirler. Yapay sinir ağları, yapay sinir hücrelerinin birbirleriyle bağlantılar aracıllı̆ıyla bir araya gelmeleri ile oluşan yapılardır. Yapay sinir ağları üç katmanda incelenir; giriş katmanı, ara (gizli) katmanlar ve çıkış katmanı. Bir yapay sinir ağının yapısı Şekil 1'de gösterilmiştir.

Giriş Katmanı: Yapay sinir ağılarına dış dünyanın yardımıyla elde edilen girdilerin geldiği katmandır. Giriş katmanına gelen girdiler hiçbir işlem görmeden alt katmanlara iletilir.

Ara (Gizli) Katman (lar): Giriş katmanından çıkan bilgiler ara ya da gizli katmana gelir ve bu katmanların sayısı ağlara göre farklılık gösterir. Bazı ağlarda birden fazla ara katman bulunabilmektedir. Bu katmandaki nöronların sayısı giriş ve çıkış katmanlarının sayıları ile bağımlı değildir. 


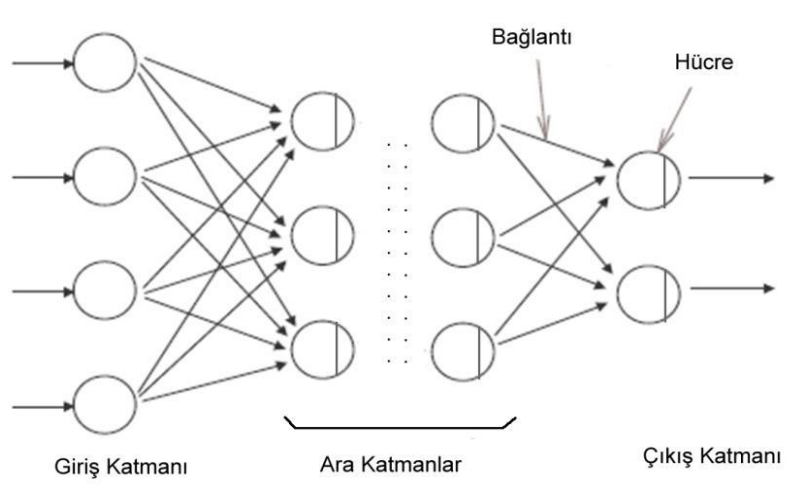

Şekil 1. Yapay Sinir Ağının Yapısı

Kaynak: Çayıroğlu İ. (2015: 7). Yapay Sinir Ağları. Karabük Üniversitesi, Karabük, Türkiye.

Ara katman ve bu katmanların nöron sayılarının artmasıyla oluşan hesaplama karmaşıklığı gibi sorunlar ile karşılaşıldığında yapay sinir ağı bu problemlerin çözümünde kolaylık sağlamaktadır.

Çıkış Katmanı: Ara katmandan gelen bilgileri toplayarak, ağın çıktılarını üreten katmandır. Çıkış katmanında üretilen çıktılar veri olarak dış dünyaya gönderilir.

\subsection{Yapay Sinir Ağlarının Eğitimi ve Testi}

Bir YSA'nın eğitilmesi işlemi, süreç elemanlarının birbiri ile olan bağlantılarına ait ağırlık değerlerinin belirlenmesi işlemidir. İlk olarak bu ağırlıkların değerleri rastgele olarak atanmaktadır. Ancak yapay sinir ağlarında örneklerle desteklendikçe bu değerler güncellenir. Buradaki amaç örnekler yardımıyla gerçekleşebilecek değer ağırlıklarını bulmaktır. $\mathrm{Bu}$ örnekler eğitilecek olan ağa birçok kez göstererek gerçek değerlere ulaşabilmesini sağlamaktır. Ağın gerçek ağırlık değerlerini sağlaması, verilen örneğe ait genelleştirme özelliğine sahip olmasını sağlamaktadır. Ağın bu genelleştirme özelliğine sahip olmasına ağın öğrenmesi denmektedir.

Yapay sinir ağında öğrenme olayının iki aşaması vardır. İlk önce örnek olarak gösterilen değerleri ile üreteceği çıktı belirlenir. Elde edilen çıktıların doğruluk derecesine göre diğer aşamaya geçilir. Bu aşamada da elde edilen ağın bağlantılarının ağırlıkları değiştirilir. Buna göre ağın çıktısının belirlenmesi ve ağırlıklarının değiştirilmesi ağın öğrenme kuralı ile farklı şekillerde olmaktadır.

Yapay sinir ağlarında ağın test edilmesi, ağın eğitiminin 
tamamlanmasından sonra ağın öğrenip öğrenmediğini ölçmek için yapılan denemelerdir. A $\breve{g}$ görmediği farklı örneklerle test edilmektedir. Bu test sırasında ağın ağırlık değerlerinde herhangi bir değişiklik yapılmaz. Yapılan testin örnekleri ağa gösterilir. Ağın eğitimi sırasında belirlenmiş olan bağlantı ağırlıklarını kullanarak örnekler için çıktılar üretir. Bu çıktılar gerçeğe yakınlık derecelerine bakılarak ağın eğitimi ile ilgili bilgiler veririler. Sonuçlar gerçek değerlere ne kadar yakın olursa ağın eğitimin öğrenme gücü de o kadar iyidir. Yapay sinir ağlarında eğitim için kullanılan verilere eğitim seti, test için kullanılan verilere ise test seti denmektedir. Yapay sinir ağlarında adaptif öğrenme, ağa sunulan veriler ile bilinmeyen veriler hakkında yorum yapabilme yeteneğidir (Öztemel, 2016, s. 55).

\section{LITERATÜR ARAŞTIRMASI}

Yapay sinir ağları birçok alanda kullanılmaktadır. Burada da yapay sinir ağları ve regresyon analizi ile karşılaştırmalar yapılan çalışmalar yer almaktadır.

Nguyen ve Cripps (2001), konut satış tahmini için yapay sinir ağlarının öngörülen performansını ve çoklu regresyon analizini karşılaştırmaktadır. Çalışmada kurulan model için bağımlı değişken konutun satış değeri, bağımsız değişkenler ise konutun $\mathrm{m}^{2}$ si, oda sayısı, banyo sayısı, yaşı, garajın olup olmaması ve muhiti olarak ele alınmıştır. Veriler 1993-1994 yılları arasında 18 ayın değerlerini kapsamaktadır.

Öztürk ve Fitöz (2009), konut arz ve taleplerini etkileyen değişkenler regresyon analizi ile belirlenmiştir. Konut talebi bağımlı ve kişi başına milli gelir, konut fiyatları, faiz oranları ve demografik değişkenler ele alınmıştır. Burada konut talebi ile kişi başına mili gelir, konut fiyatları ve faiz oranları arasında pozitif yönlü, demografik değişkenler arasında ise negatif yönlü bir ilişki bulunmuştur. Konut arzını etkileyen değişsenlerde kişi başına milli gelir, konut fiyatları ve M2 parasal büyüklüğüdür. Konut arzı ile kişi başına milli gelir, konut fiyatları ve M2 parasal büyüklüğü arasında pozitif yönlü bir ilişki bulunmuştur.

Zainun vd. (2010), Malezya'nın Johor Bahru şehrinde konut talebi için yapay sinir ağları yöntemi kullanılmıştır. Bağımlı değişken olarak konut talebi, bağımsız değişkenler ise nüfus artışı, doğum oranı, bebek ölüm oranı, enflasyon oranı, gelir oranı, konut sayısı, GSYH, işsizlik ve yoksulluk oranı verileri ele alınmıştır. Gerçek değerler ile tahmini değerler karşılaştırılmıştır. Hata oranı $\% 16,44$ olarak bulunmuştur. Sonuç olarak yapay sinir ağları ile konut talebinin tahmin edilebilir olması gözlemlenmiştir. 
Radzi vd. (2012)'de Malezya'daki konut fiyatlarının tahmini yapılmıştır. Bunun için 2000-2009 yılları arasındaki çeyreklik veriler kullanılmıştır. Bağımlı değişken olarak konut değişkenleri endeksi, bağımsız değişkenler ise işsizlik oranı, nüfus, ipotek oranı ve hane halkı geliri ele alınmıştır. Veriler yapay sinir ağları ile analiz edilmiştir. Bu değişkenler ile 2010-2011 yılları çeyreklik aylık veriler tahmin edilmiştir. gerçek değerler ile tahmini değerler karşılaştırılmış ve hata oranı $\% 8$ olarak bulunmuştur.

Lebe ve Akbaş (2014), 1970-2011 yılları arasındaki kişi başı gelir, konut faizi, faiz oranı, sanayileşme, tarım sektöründe istihdam ve medeni durum verileri kullanılarak konut talebi eş bütünleşme ve vektör hata düzeltme modeli ile analiz edilmiştir. Analiz sonucunda medeni durum, kişi başı gelir ve sanayileşme konut talebini pozitif yönde etkilerken, konut fiyatları, faiz ve tarım sektöründe istihdam negatif olarak etkilemektedir. Bu değişkenler arasında konut talebini en fazla etkileyen değişken ise kişi başı gelir olarak tespit edilmiştir.

Aktürk ve Tekman (2016), çalışmada Erzurum ili merkezinde ikamet eden tüketicilerin konut taleplerini etkileyen faktörler belirlenmiştir. Bu çalışma için anket hazırlanarak 640 kişiye bu anketler uygulanmıştır. Araştırma için istatistiksel uygulamalar yapılmıştır. Sonuç olarak bireylerin konut satın almaların da fiyat, müteahhit firmaların güvenirliği, konutun güvenlikli sitede olması, büyüklüğü, kullanılan malzemenin kalitesi, merkeze yakınlığı, sağlamlığı ve ferah olması gibi faktörlerin önemli olduğu tespit edilmiştir.

Uysal ve Yiğit (2016), çalışmada 1970-2015 yılları arası veri kabul edilerek konut talebini etkileyen faktörler araştırılmıştır. Konut talebini etkileyen faktörler olarak kişi başına milli gelir, fiyatlar, kentleşme hızı, faiz ve M2 parasal büyüklüğü kullanılmıştır. İlk olarak değişkenlerin birinci dereceden farkı alınmış daha sonra da Johensen ve Johensen-Juselius eş bütünleşme testi yapılmıştır. Bu test sonucunda en az iki eşbütünleşik denklem olduğu görülmüştür. Kısa ve uzun dönemli ilişkiye bakılması için de VECM modeli kullanılmıştır. $\mathrm{Bu}$ modele göre de konut birim fiyatları, kentleşme hızı, faiz oranları ile konut talebi arasında pozitif yönlü, M2 parasal büyüklüğü ve fiyat göstergesi olarak kullanılan TÜFE ile negatif yönlü bir ilişki bulunmuştur. Kukla değişkeni olarak kullanılan 1994, 1998, 2001, 2009 krizleri ile arasında negatif ilişki bulunmuştur. Konut talebinin belirleyicileri arasında en fazla etkiye sahip olan gelir değişkeni olarak tespit edilmiştir.

\section{UYGULAMA}

$\mathrm{Bu}$ çalışmada Antalya ili için konut satışlarını etkileyen faktörler 
belirlenerek YSA ve çoklu doğrusal regresyon (ÇDR) modeli ile talep tahmini yapılmıştır.

Çalışmada YSA'nın tercih edilme sebebi regresyon analizinde olduğu gibi herhangi bir ön koşula ihtiyaç duymamasıdır. Bu sayede eldeki veriler arasındaki ilişki daha kolay bir biçimde incelenebilecektir. Özellikle doğrusal olmayan ilişkilerin ortaya konmasında YSA regresyon analizine göre daha başarılı sonuçlar bulabilmektedir. $\mathrm{Bu}$ başarının sırrı ise YSA'nın insan beynindeki öğrenme sürecini taklit etmesi, öğrenme sonucunda da en küçük hata koşulu altında değişkenler arasındaki ilişkiyi ortaya koyabilmesidir.

İlk olarak literatür taraması ve uzman görüşleri doğrultusunda; konut satışlarının etkileyen faktörler konut değeri, daire sayısı, konut kredileri, konut kredi faizleri, inşaat güven endeksi, TÜFE, nüfus, GSYH, konut fiyat endeksleri, döviz ve demografik değişkenler olan ailedeki kişi sayısı, işsizlik, istihdam olarak seçilmiştir. Bağımlı değişken olarak seçilen konut satışları değişkeni, aylık gözlemlerden oluştuğu için aylık olarak gözlemlenmeyen GSYH ve nüfus değişkenleri elenmiştir. Ele alının tüm değişkenlere ait 20132017 dönemlerine ait aylık gözlemler kullanılmıştır. İlgili tüm veriler T.C. Merkez Bankası'nın Elektronik Veri Dağıtım Sistemi'nden (EVDS) alınmıştır.

Geliştirilen modellerin eğitimi için 2013-2016 yıllarına ait gözlemler, test için ise 2017 yılına ait değerler kullanılmıştır. Daha sonra yapılan ÇDR analizi varsayımları sağlaması için TÜFE, konut fiyat endeksleri, döviz ve demografik değişkenleri de modelden çıkarılmıştır ve aylık konut satışları; daire sayısı, konut değerleri, konut kredileri, konut kredi faizleri ve inşaat güven endeksi ile tahmin edilmeye çalışılmıştır. Birebir karşılaştırma olması için ÇDR ile YSA analizinde aynı değişkenler kullanılmıştır. Çoklu doğrusal regresyon modeli analizi için Eviews, yapay sinir ağlarının analizi için Matlab programı kullanılmıştır.

\section{1. Çoklu Doğrusal Regresyon Analizi}

Yapılan analizler sonucunda elde edilecek modelin güvenilir ve kullanılabilir olması için en küçük kareler yöntemi varsayımlarını yerine getirmesi gerekmektedir. $\mathrm{Bu}$ varsayımlar ana kütle hata terimi ve bağımsız değişken ile ilgili olan varsayımlardır. Bu varsayımlar;

- Çoklu doğrusal bağlılık varsayımı

- Değişen varyans varsayımı

- Normal dağılım varsayımı

- Otokorelasyon varsayımı 


\section{Çoklu Doğrusal Bağlılık}

Çoklu doğrusal bağlılık varsayımında bağımsız değişkenler arasında ilişki olup olmadığına bakılmaktadır. Bu varsayım VIF (variance inflation factor - varyans genişlik faktörü) analizi yapılarak test edilmektedir. VIF analizi sonucunda çıkan değerlerin 10'dan küçük olması beklenmektedir. 10'dan büyük olmas1 durumunda bağımsız değişkenler arasında ilişki olduğundan şüphelenilmesi gerekilmelidir. Yapılan VIF analizi sonucunda en büyük değer 6,86 olarak bulunmuştur. Bu da kurulan modelde bağımsız değişkenler arasında ilişki olmadığını göstermektedir.

\section{Değişen Varyans}

Değişen varyans varsayımı hata terimlerinin varyanslarının farklı olup olmadığı varsayımıdır. Bu teoriye göre bağımsız değişkenlerin varyanslarının farlılık göstermesi sonucunda hata teriminin de bu değişime ayak uydurması sonucunda farklı varyansa sahip olmasıdır. Elde edilen regresyon analizi ile değişen varyans varsayımını analiz etmek için White testi yapılmıştır. White testi sonucunda $\mathrm{P}=0,86>0,05$ olarak hesaplanmıştır. Buna göre yokluk hipotezi kabul edilmektedir. Yani kurulan model için hata terimleri eşit varyanslıdır.

\section{Normal Dağılım}

Normal dağılım varsayımı yapılan regresyon analizine ait modelin hata terimine göre uygulanmaktadır. Bu nedenle hata terimi normal dağılıma sahip olmalıdır. Jarque Bera normal dağılım analizine göre $\mathrm{P}=0,89>0,05$ olduğundan yokluk hipotezi reddedilemez. Yani hata terimleri normal dağılıma sahiptir.

\section{Otokorelasyon}

Otokorelasyon yani hata terimlerinin önceki dönemler ile arasında ilişki olup olamadığ 1 varsayımıdır. Bu varsayıma göre otokorelasyon analizi için Breusch- Godfrey testi yapılmıştır. Yapılan Breusch- Godfrey analizi sonucunda $\mathrm{P}=0,60>0,05$ olduğundan yokluk hipotezi kabul edilmektedir. Yani analiz edilen model de otokorelasyon sorunu yoktur.

Antalya ili için 01.2013-12.2017 yılları arasında aylık konut satışını etkileyen bağımsız değişkenler aşağıdaki gibi tanımlanmıştır. Model Eviews programı ile analiz edilerek yorumlanmıştır. Regresyon analizi sonuçları Tablo 1 'de verilmiştir. 


\author{
$Y$ : Aylık Konut Satışı \\ $X_{I}$ : Konut Değerleri \\ $X_{2}$ : İnşaat Güven Endeksi \\ $X_{3}$ : Konut Kredileri \\ $X_{4}$ : Konut Kredi Faizleri
}

Elde edilen model:

$Y=0,0000035 X_{1}+51,242 X_{2}+0,000976 X_{3}-292,6102 X_{4}$

(1)

Tablo 1: Regresyon Analizi Sonuçları

\begin{tabular}{|c|c|c|c|c|}
\hline $\begin{array}{c}\text { Bağımlı Değişken: } \\
\text { Aylık Konut Satıșı (Y) }\end{array}$ & Katsayı & $\begin{array}{c}\text { Standart } \\
\text { Hata }\end{array}$ & $t$ ist. & $p$ \\
\hline Konut Değerleri $\left(\mathrm{X}_{1}\right)$ & 0,0000035 & 0,00 & 4,61 & $0,00^{*}$ \\
\hline İnşaat Güven Endeksi $\left(\mathbf{X}_{2}\right)$ & 51,242 & 2,36 & 21,65 & $0,00^{*}$ \\
\hline$* * *(\mathbf{d})$ Konut Kredileri $\left(\mathbf{X}_{\mathbf{3}}\right)$ & 0,000976 & 0,00 & 4,35 & $0,00 *$ \\
\hline $\begin{array}{c}* * *(\mathbf{d}) \text { Konut Kredileri Faizi } \\
\left(\mathbf{X}_{4}\right)\end{array}$ & $-292,6102$ & 153,3871 & 4,61 & $0,06 * *$ \\
\hline \multicolumn{5}{|l|}{ Mak, VIF $=6,43$} \\
\hline \multicolumn{5}{|c|}{ Kalıntılar için White değişen varyans testi $P=0,86>0,05$} \\
\hline \multicolumn{5}{|c|}{ Kalıntılar için Jarque- Bera normallik testi $P=0,60>0,05$} \\
\hline \multicolumn{4}{|c|}{ Kalıntılar için Breusch- Godfrey otokorelasyon testi $P=\mathbf{0 , 6 0}$} & \\
\hline \multicolumn{5}{|c|}{ * 0,05 düzeyinde anlamlı. } \\
\hline \multicolumn{5}{|l|}{$* * 0,10$ düzeyinde anlamlı. } \\
\hline
\end{tabular}

Model oluşturulurken elde edilen değişkenlerin zaman serisi olmasından dolayı durağan olmayan değişkenler birim kök testi ile durağanlaştırılmıştır. Durağan olmayan değişkenler konut kredileri ve konut kredi faizleri olarak belirlemiştir. $\mathrm{Bu}$ değişkenler 1 . derecede durağan olup modele durağan şekilde dahil edilmiştir. Analiz sonucunda $\mathrm{P}=0,0<0,5$ olduğundan dolayı model anlamlıdır. $\mathrm{R}^{2}=0,51$ olarak bulunmuştur. Yani konut değerleri, inşaat güven endeksi, konut kredileri ve konut kredi faizi aylık konut satışlarının \% 51'ini açıklamaktadır. Sabit katsayı anlamsız olduğu için modele dahil edilmemiştir. 
Konut değerleri $\left(X_{1}\right)$ değişkenine bakıldığında $\mathrm{P}=0,00<0,05$ olduğundan aylık konut satışı üzerinde anlamlı bir etkisi vardır. Konut değerleri ve aylık konut satışları arasında aynı yönde ilişki olup konut değerlerinde meydana gelecek bir birimlik artış/azalış aylık konut satışlarını 0,0000035 birim kadar artışa/azalışa neden olacaktır. Genel olarak bakıldığında konut fiyatlarının artması konut satışlarının ters yönde etkilemesi beklenmektedir. Ancak modele bakıldığında aynı yönde etkilediği görülmektedir. Bu da tüketicilerin konut fiyatlarının gelecek dönem de artması yönünde beklentilerini arttırmasından dolayı konut sahibi olmayı ertelemek istemediklerini göstermektedir ve yatırım amaçlı alınan konutların o anki fiyatıyla alıp daha sonra satışını yapmak istediklerinden kaynaklı olabilmektedir. Genel olarak bakıldığında konut değerlerinin konut satışları üzerinde diğer değişkenlere göre daha az bir etkisi bulunmaktadır. Bunun nedeni de çoğu bireyin bankalarca verilen konut kredilerini kullanarak ev sahibi olmasıdır.

İnşaat güven endeksi $\left(X_{2}\right)$ değişkenine bakıldığında $\mathrm{P}=0,00<0,05$ olduğundan aylık konut satışları üzerinde anlamlı bir etkisi vardır. İnşaat güven endeksi ile aylık konut satışı arasında aynı yönde bir ilişki olup inşaat güven endeksindeki bir birimlik atış/azalış aylık konut satışlarında 51,242 birim kadar artış/azalış meydana getirmektedir. Tüketicilerin sektörel gelişim olarak ele aldıkları değişimlerin gözlemlenmesi sonucunda inşaat sektörüne olan ekonomik güvenin artması sonucunda konut satışının artması durumunu göstermektedir.

Konut kredileri $\left(X_{3}\right)$ değişkenine bakıldığında $\mathrm{P}=0,0001<0,05$ aylık konut satışları üzerinde anlamlı bir etkisi vardır. Konut kredileri ile aylık konut satışı arasında aynı yönde ilişki bulunmaktadır. Yani konut kredilerindeki bir birimlik artış/azalış aylık konut satışını 0,000976 birim kadar artış/azalışa neden olmaktadır. Bireylerin konut alırken toplu olarak para birikimlerinin olmaması durumunda bankalarca verilen konut kredilerine olan taleplerin artmasıdır. Günümüzde birçok banka çeşitli krediler ve çeşitli ödeme şekilleri ile bireylerin ihtiyaçlarını karşılamaktadır. Bireylerin istek ve taleplerine uygun konutları bulması durumunda konutu alabilmek için konut kredilerine başvurmaktadır ve böylece konut satışları da artmaktadır.

Konut kredileri faizi $\left(X_{4}\right)$ değişkeni incelendiğinde $\mathrm{P}=0,06<0,10$ olduğundan 0,10 anlamlılık düzeyinde bütün bağımsız değişkenlerin aylık konut satı̧ı üzerinde anlamlı bir etkisi bulunmaktadır. Konut kredileri faizi ile aylık konut satı̧ları arasında ise zıt yönlü bir ilişki vardır. Yani konut kredi faizlerinde meydana gelen bir birimlik artışta aylık konut satışlarında -292,61 birimlik azalış meydana gelecektir. Bankalar tarafından verilen konut 
kredilerine uygulanan faizlerin yüksek değerlerinden dolayı bireylerin bu faizleri ödemekten kaçınması durumunda aylık konut satışlarının olumsuz etkilemektedir. Bankalarca verilen krediler evin özelliklerine göre belirlenen fiyatına karşılık faizlerin günümüzde alınan kredilerden daha fazla olması göz önünde bulundurulursa bireylerin konut talebini olumsuz etkilemektedir.

Genel olarak bakıldığında aylık konut satışları üzerinde en yüksek etkiye sahip olan değişken inşaat güven endeksi olup sırasıyla konut kredileri, konut kredi faizi ve konut değerleri olarak sıralanmaktadır. İnşaat güven endeksinin model üzerinde anlamlı ve ayn yönde etkisi bulunmaktadır. İnşaat sektörünün gelişmesi tüketicinin ilgisini çekmektedir. Her geçen gün gelişmesi ve konut fiyatlarının artmasıyla birlikte tüketiciler gelecek dönemde de aynı etkiye sahip olacağını öngörmekte ve hem yatırım hem de kullanma amaçlı konut talep etmektedir. Örneğin, gelişen teknoloji ile yapılan yeni konutların özellikleri de artmaktadır. Maddi gücü yüksek bireyler de yapılan yeni konutlara taleplerini arttırmaktadır. Aynı zamanda bulundukları konutu da satışa çıkarmaktadır ve sahip oldukları konutun özelliklerinin diğerine göre daha az olmasından dolayı fiyatı da düşük olacaktır. Diğer maddi gücü daha düşük olan bireyler de satışa çıkan bu konutu talep edeceklerdir. Bu döngü devam edecektir. Bir diğer değişken olan konut kredileri de konut satışını etkilemektedir. Tüketicilerin sahip olmak istedikleri konutlar için ellerinde nakit ve toplu para bulunmadığ 1 durumlarda bankalar tarafindan verilen kredileri talep etmektedirler. Bankaların çeşitli ödeme şekillerinden yararlanarak kira öder gibi ev sahibi olabilmektedirler. Konut kredi faizi aylık konut satışı üzerinde olumsuz bir etkiye sahiptir. Bunun nedeni ise bankalar tarafindan verilen kredilerin geri ödeme süresine göre üzerine koydukları faizlerdir. $\mathrm{Bu}$ faizlerin konutun değerinden daha fazla olması tüketicileri konut taleplerini olumsuz etkilemektedir. Son olarak konutların değerleri de konut satışlarını etkilemektedir. Fakat diğer değişkenlere göre daha az etkilemektedir. Bunun nedeni de yapılan teşvikler ve kampanyalar olarak görülmektedir. $\mathrm{Bu}$ kampanyalar ile düşük vadeli ve uzun ödeme seçenekleri, peşinat indirimleri gibi teşviklerin sunulması konut fiyatları artsa da konut satışlarını da güçlendirmektedir.

\subsection{Yapay Sinir Ağları ile Konut Satışlarının Tahmini}

Çalışmada regresyon analizi ile elde edilen sonuçlar YSA modeli ile kiyaslanacaktır.

Antalya ili için aylık konut satışlarının tahmini yapay sinir ağları ile yapılmaktadır. Bunun için ilk olarak aylık konut satışlarının etkileyen faktörler 
araştırılmıştır. Yapılan bu tahmin için aylık konut satışları regresyon analizi için bağımlı değişken iken yapay sinir ağı modeli için çıktı değişkeni olarak ele alınmıştır. Aynı zamanda regresyon modeli için bağımsız değişken olan konut değerleri, inşaat güven endeksi, konut kredileri ve konut kredi faizleri ise yapay sinir ağlarında girdi nöronu olarak ele alınmıştır. Oluşturulacak YSA modelinde üç ana katman vardır. Bunlar girdi katmanı, gizli katman ve çıktı katmanıdır. Veriler rastgele iki bölüme ayrılmış ve toplam verilerin \%80'i eğitim, \%20'si ise test verisi olarak kullanılmıştır. Öncelikle hem girdi hem de çıktı verilerine normalizasyon yapılarak $[0,1]$ aralığına dönüştürülmüsstür.

Yapay sinir ağlarında etkinleştirme fonksiyonu olarak 3 alternatif kullanılmaktadır: tansing, purelin ve logsing. En iyi ağ yapısını bulmak için çeşitli denemeler yapılmıştır. Bu denemelerde giriş katmanı - gizli katman ve gizli katman - çıktı katmanı arasındaki etkinleştirme fonksiyonları için her 3 fonksiyonun mümkün olan bütün kombinasyonları denenmiştir. Bu süreç gizli katman için seçilen 5, 10, 15 ve 20 nöron yapısı için tekrar edilmiş ve toplam 36 farklı ağ yapısı tespit edilmiştir. Her bir kombinasyon için 10 deneme yapılarak her birindeki hata değerleri kontrol edilmiştir. Örneğin tansing 5 logsin olası mimarisi; tansig aktivasyon fonksiyonu - gizli katmanda 5 nöron - logsig aktivasyon fonksiyonu anlamına gelmektedir.

En iyi ağ yapısı seçilen performans ölçütüne göre belirlenmektedir. $\mathrm{Bu}$ çalışmada performans ölçüsü olarak MSE (ortalama hata kare) değeri seçilmiştir. En iyi ağın seçilmesi MSE’nin değerine bağlıdır. Bu şebekede MSE 0,0076 'dır. En iyi ağın giriş katmanında 4 nöron gizli katmanında 15 nöron ve çıktı katmanında da 1 nöron vardır. Gizli katmanı ve çıktı katmanının her ikisi için de sigmoid (logsig) fonksiyonu kullanılmıştır.

\subsection{Tahmin Analizlerinin Karşılaştırılması}

Yapay sinir ağları ve çoklu doğrusal regresyon analizi ile yapılan tahmin sonuçları Tablo 2'de karşılaştırılmıştır. Burada her bir test verisinin geçekleşen değerleri ve tahmini değerleri karşılaştırılmıştır. Aynı zamanda her bir test verisi için hata oranları da karşılaştırılmıştır. 
Tablo 2: YSA ve ÇDR Modeli Tahminlerini ile Gerçek Değerler ile Karşılaştırılması

\begin{tabular}{|c|c|c|c|c|c|c|c|}
\hline TARİH & $\begin{array}{l}\text { GERÇEK } \\
\text { DEĞERLER }\end{array}$ & $\begin{array}{l}\text { ÇDR } \\
\text { TAHMIN }\end{array}$ & $\begin{array}{l}\text { ÇDR } \\
\text { TAHMIN } \\
\text { HATA }(\%)\end{array}$ & $\begin{array}{l}\text { ÇDR } \\
\text { MUTLAK } \\
\text { HATA }(\%)\end{array}$ & $\begin{array}{l}\text { YSA } \\
\text { TAHMIN }\end{array}$ & $\begin{array}{l}\text { YSA } \\
\text { TAHMIN } \\
\text { HATA }(\%)\end{array}$ & $\begin{array}{l}\text { YSA } \\
\text { MUTLAK } \\
\text { HATA }(\%)\end{array}$ \\
\hline 01.2017 & 4324 & 4798 & $-10,96$ & 10,96 & 4352 & $-0,64$ & 0,64 \\
\hline 02.2017 & 4673 & 4803 & $-2,78$ & 2,78 & 4673 & 0,08 & 0,08 \\
\hline 03.2017 & 5516 & 5800 & $-5,15$ & 5,15 & 5623 & $-1,93$ & 1,93 \\
\hline 04.2017 & 4818 & 5579 & $-15,79$ & 15,79 & 4903 & $-1,76$ & 1,76 \\
\hline 05.2017 & 5243 & 5624 & $-7,27$ & 7,27 & 5258 & $-0,28$ & 0,28 \\
\hline 06.2017 & 4253 & 5362 & $-26,08$ & 26,08 & 4234 & 0,44 & 0,44 \\
\hline 07.2017 & 4827 & 5373 & $-11,31$ & 11,31 & 4819 & 0,16 & 0,16 \\
\hline 08.2017 & 4475 & 5822 & $-30,1$ & 30,1 & 4527 & $-1,16$ & 1,16 \\
\hline 09.2017 & 5293 & 5469 & $-3,33$ & 3,33 & 5345 & $-0,98$ & 0,98 \\
\hline 10.2017 & 5394 & 5431 & $-0,69$ & 0,69 & 5358 & 0,66 & 0,66 \\
\hline 11.2017 & 5563 & 5664 & $-1,82$ & 1,82 & 5539 & 0,74 & 0,74 \\
\hline \multirow[t]{2}{*}{12.2017} & 5894 & 5865 & 0,49 & 0,49 & 5872 & 0,37 & 0,37 \\
\hline & & & OMYH & 9 & & OМYH & 1 \\
\hline
\end{tabular}

Tablo 2'de görüldüğü gibi YSA'nın tahmin hatası ÇDR modeline göre daha düşük değerler sahiptir. Tabloda ilk olarak yüzde tahmin hatası (gerçek değer ile tahmin değeri farkının gerçek gözlem değerine oranlanması) verilmiş bu sayede tahmindeki sapmanın yönü pozitif veya negatif olarak ortaya konmuştur. Mutlak hata sütununda ise mutlak hata değerleri ve sütunun en altında ortalama mutlak yüzde hata değeri (OMYH) verilmiş ve her iki yöntem OMYH ile karşılaş̧ırılmışıtır. YSA tahmini ve regresyon tahmininin ortalama mutlak yüzde hata oranları sırasıyla $\% 1$ ile $\% 9$ olarak bulunmuştur. YSA, ÇDR

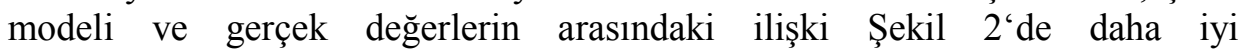
gözlemlenmektedir. 


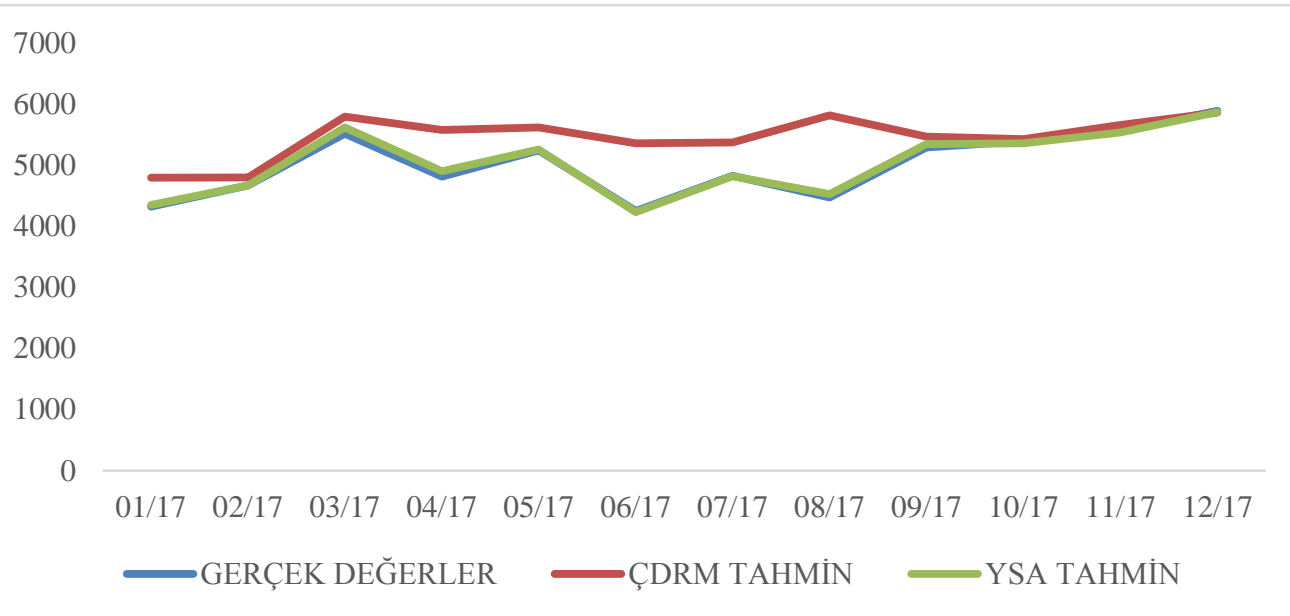

Şekil 2: YSA Tahmin Modeli, ÇDR Tahmini ile Gerçek Değerlerin Karşılaştırılması

Şekil 2'de görüldüğü gibi YSA ile tahmin edilen değerlerin birbirine örtüssen yapıda olduğu ve sapmaların aşırılık göstermediği görülmektedir. ÇDR modeli ise genel olarak trendi yakaladığı gözlemlenmiş ancak gerçek ve tahmin değerleri arasındaki fark oldukça yüksektir. Yapılan karşılaştırmalar ve analizler sonucunda kurulan YSA modelinin ÇDR modeli göre daha başarılı sonuçlar elde edildiği görülmüştür.

\section{SONUÇLAR}

İnşaat sektörü ekonomik kalkınma, işsizliğin azalması ve toplumsal refahın iyileştirilmesi için önemli bir paya sahiptir. Gerek çiftlerin evlenmesi ve boşanması gerekse de yatırım amaçlı olarak satın alınması sebebiyle konut talebinin canlılığ sürekli olmaktadır. Bu çalışmada son zamanlarda gelişmekte olan konut sektörünün Antalya ili için tahmin analizi yapılmıştır.

Çalışmada çok değişkenli regresyon analizi ile elde edilecek olan talep tahmini modelinin yapay sinir ağları ile karşılaştırılması amaçlanmıştır. $\mathrm{Bu}$ sayede karar vericiler için tutarlı bir karar destek modeli ortaya konabilecektir. Talepteki değişimlerin önceden tespit edilmesinin yardımıyla kaynakların daha etkin kullanılması mümkün olacaktır.

Regresyon analizinin yapılabilmesi ve doğru sonuçlar elde etmek için temel varsayımları test edilmiştir. $\mathrm{Bu}$ varsayımlara uygun değişkenler konut değerleri, konut kredileri, konut kredi faizleri ve inşaat güven endeksi olarak model analiz edilmiştir. Değişkenlerin 01.2013-12.2017 yılları arasındaki 
gözlem değerleri ele alınmıştır. Bu gözlem değerlerinin 2013-2016 yılları arasındaki veriler ile analiz yapılmış ve 01.2017-12.2017 ayları arasındaki veriler ile de analiz test edilmiştir. Yapılan analizi sonucunda model $\% 90$ güven düzeyinde anlamlı olarak bulunmuştur ve bağımsız değişkenler bağımlı değişkenin \%51'ini açıklamaktadır.

Yapılacak olan karşılaştırmanın birebir olması için yapay sinir ağlarında da aynı değişkenler kullanılmıştır. Çeşitli denemeler sonucu en iyi ağ modeli belirlenmiştir. Elde edilen model test verileri için çalıştırılmış ve 2017 yılına ait tahminler hesaplanmıştır. Yapay sinir ağları ile elde edilen tahminlerin gerçek değerlerle yapılan karşılaştırılması sonucunda hata oranı \%1 olarak bulunmuştur. Bulunan değer regresyon modeli için bulunan \%9'dan oldukça iyidir.

Uygulamada yöntemlerin eşit bir şekilde karşılaştırılabilmesi için regresyon analizinin varsayımlarını karşılayan dört farklı değişken kullanılmıştır. Bu çalışma için kullanılan verilerin yanı sıra farklı veriler ile de diğer şehirler veya Türkiye için tahmin modelleri oluşturulabilir. Analiz için kullanılan bağımsız veya girdi değişkenlerinden olan konut kredileri, konut değeri, daire sayısı ve konut kredi faizlerini de etkileyen değişkenler bulunarak her biri için tahmin analizleri yapılabilir.

\section{KAYNAKÇA}

Aktürk, E., \& Tekman, N. (2016). Konut Talebi ve Erzurum Kent Merkezinde Tüketicilerin Konut Edinme Kararlarını Etkileyen Faktörler. Atatürk Üniversitesi İktisadi ve İdari Bilimler Dergisi, 30(2), 423-440.

Çayıroğlu, İ. (2015). Yapay Sinir Ağları. Karabük Üniversitesi, Karabük, Türkiye.

Kobu, B. (2014). Üretim Yönetimi. Yazın Basın Yayın, İstanbul, Türkiye.

Lebe, F., \& Akbaş Y. (2014). Türkiye'nin Konut Talebinin Analizi. Atatürk Üniversitesi İktisadi ve İdari Bilimler Dergisi, 28, 57-83.

Nahmias, S. (2009). Production and Operations Analysis. Visual Library, Boston, Amerika.

Nguyen, N., \& Cripps, A. (2001). Predicting Housing Value: A Comparison of Multiple Regression Analysis and Artificial Neural Networks. Journal of Real Estate Research, 3(22), 313-336.

Öztemel, E. (2016). Yapay Sinir Ağları. Papatya Bilim Yayınevi, İstanbul, Türkiye. 
Öztürk, N., \& Fitöz, E. (2009). Türkiye'de Konut Piyasasının Belirleyicileri: Ampirik Bir Uygulama. Zonguldak Karaelmas Üniversitesi Sosyal Bilimler Dergisi, 5(10), 21-46.

Radzi, M., Muthuveerappan, C., Kamaridun, N., \& Mohammead, I. (2012). Forecasting House Price Index Using Artificial Neural Network. International Journal of Real Estate Studies, 7(1).

Reid, R.D., \& Sanders, N.R. (2011). Operations Management. Oucbecor World-Versailles, Amerika.

Tekin, M. (1996). Üretim Yönetimi. Arı Yayıncılık, Konya, Türkiye.

Top A, Yılmaz E. (2009). Üretim Yönetimi. Yaprak Yayınları, İstanbul, Türkiye.

Uysal, D., \& Yiğit, M. (2016). Türkiye'de Konut Talebinin Belirleyicileri (1970-2015): Ampirik Bir Çalışma. Selçuk Üniversitesi Sosyal Bilimler Meslek Yüksekokulu Dergisi, 19(1), 185-209.

Üreten, S. (2006). Üretim/İşlemler Yönetimi. Gazi Kitapevi, Ankara, Türkiye.

Zainun, N., Rahman, A., \& Eftekhari, M. (2010). Forecasting Low-Cost Housing Demand in Johor Bahru, Malaysia Using Artificial Neural Network(ANN). Journal of Mathematics Research, 2(1), 14-19. 